\section{Secret history}

\section{Nicholas Kurti}

Operation Epsilon: The Farm Hall Transcripts. Institute of Physics Publishing: 1993. Pp. 313. £14.95. US distributor, University of California Press.

ON 3 July 1945, ten prominent German scientists involved in the German wartime Atomic Energy Project arrived at Farm Hall, a country house near Cambridge in England, where they remained for 6 months. Their whereabouts were kept secret, their communications with their families were sporadic and slow and they were kept in darkness about the reasons for their internment.

Their conversations, picked up by microphones, were continuously monitored. Anything nontrivial was recorded on shellac-covered reusable disks and most of these recordings were transcribed by the 'listeners'. The two officers in charge (Major T. H. Rittner and Captain P. L. C. Brodie) analysed the transcripts, had part of them translated and summarized the rest. These translations, summaries and the officers' comments on the operation, code-named Epsilon, formed the Farm Hall reports, numbered FH1FH23/24 and classified TOP SECRET.

Their existence was first surmised when Samuel Goudsmit, the leader of the American Scientific Intelligence Mission ALSOS, reported in 1947 in his book the reactions of the German scientists on hearing the news of the Hiroshima bomb. First, they did not believe that it was an atomic bomb; then, seeing their faith in German scientific superiority shattered, they were dejected and in despair. But, according to Goudsmit, they then decided to stress the fact that they had been working only on nuclear reactors and that the community of German scientists would never have consented to work on the bomb. It is ironic that Goudsmit's suggestion, now known to be ill-founded, of a plot to explain away the nonexistence of a German bomb, should have become years later, in the writings of R. Jungk, L. Sciascia, W. Kaempfert and T. Powers, the legend that moral scruples prevented German scientists from developing the bomb*. Thus, comparing the attitudes of the Allied and the German scientists, Sciascia wrote that the Germans "were worried by the bomb, afraid, anguished, while the Allies conceived it, studied it, got it ready for use without hesitating, indeed almost lightheartedly and handed it over ... to the politicians and warmongers". To the best of my knowledge, this legend was never explicitly disowned by the German scientists. To get to the

*See, for example, Nature 359, 473 (1992), 362, 117 (1993) and 363,311 (1993). truth there were many attempts by scientists and historians to have the Farm Hall documents de-classified, but the answer was always a firm 'no', with a reminder that the Lord Chancellor (Lord Mackay), the ultimate authority in this matter, was under no obligation to give the reason for his decision.

It was then thought that, where all else had failed, a direct approach to the Lord Chancellor might succeed. A letter signed by 17 scientists and historians headed by the presidents of the Royal Society and of the British Academy was accordingly despatched on 23 December 1991 to the Lord Chancellor who, on 13 February 1992, informed the president of the Royal Society that the Farm Hall documents would be released to the Public Record Office on 14 February.

These documents are now available in book form, thanks to the laudable enterprise of Institute of Physics Publishing. It is a handsome volume with an excellent introduction by Sir Charles Frank that puts uninformed readers in the picture and helps them to get the gist of the often confused conversations.

As to the absence of work on the bomb in Germany, Frank suggests that this may have been due to the gross overestimate by Heisenberg of the critical mass for an explosion in ${ }^{235} \mathrm{U}$ and he believes that the Allies would have reached the same conclusion but for the fact that in March 1940 Otto Frisch and Rudolph Peierls seriously underestimated the critical mass. There is a fundamental difference between the two approaches. Frisch and Peierls, using for fission cross-section a value estimated from theory, calculated the critical mass to be $600 \mathrm{~g}$. Even a four-times smaller value for the cross-section would have given a bomb of only about $30-40 \mathrm{~kg}$, nothing like the 500 or $5,000 \mathrm{~kg}$ mentioned (p. 73) five years later by Heisenberg, who admits that "we don't know the order of magnitude. We can assume that they [the Allies] have some method of separating isotopes of which we have no idea." It is significant that the gaseous diffusion separation plant proposed by F. E. Simon (December 1940) was designed to produce enough ${ }^{235} \mathrm{U}$ for a dozen $30-\mathrm{kg}$ bombs a year. In brief, the Frisch-Peierls memorandum together with the Simon report gave a sober assessment of the feasibility of an atomic bomb, and to my knowledge there is nothing in contemporary German archives approaching the scientific and technical contents of those reports.

In his "Archival Note", Frank gives interesting details about the two sets of Farm Hall reports, one in the UK Public Record Office and the other in the American National Archives. The United States declassified the Farm Hall reports in August 1961 but, because of the UK embargo, they could not be made available under the Freedom of Information Act.
What fraction of the words spoken at Farm Hall are reprinted verbatim in the reports? On the evening of 6 August, after the news about the Hiroshima bomb, the conversations went on for seven-and-ahalf hours, but only about 50 minutes (10 per cent) is reproduced, the rest is summarized. For the whole six months of Operation Epsilon, there are only four hours of verbatim reporting. Moreover, as is now officially admitted, the transcripts from the original recordings - in other words the prime historical material - no longer exist. This is worrying and one can but hope that historians and archivists will try to find out whether this was an isolated case of carelessness, an act of stealthy censorship or the result of an attitude that would regard material in a foreign language as disposable once it had been translated into English.

Although the title of the book is, as Frank points out, a misnomer, this in no way detracts from the volume's value. It sheds light both on the 'guests' and on their 'hosts'. It is fascinating to observe the varied and ever-changing moods and attitudes of the scientists: truculence and good-humoured resignation, complaints and compliments, despair and hope alternate and merge. Moral scruples about working on the atomic bomb are not evident. Equally interesting is the attitude of the 'hosts': the two officers did their best for their guests but without much help from above. It seems that Operation Epsilon had no clear purpose and was organized impromptu. An example: the scientists were not freed until 3 January 1946, therefore preventing them from spending Christmas with their families.

This book will remain for many years a happy hunting ground for historians, political scientists and psychologists.

Nicholas Kurti is in the Department of Engineering Science, University of Oxford, Parks Road, Oxford OX1 3PJ, UK.

\section{New in paperback}

Consciousness Explained by Daniel C. Dennett. Penguin, $£ 7.99$. For a review, see Nature 356, 26 (1992)

Left Hander by Stanley Coren. John Murray, £9.99. See Nature 356, 637 (1992).

The Computer from Pascal to von Neumann by Herman H. Goldstine. Princeton University Press, $\$ 23.50$ £13. See Nature 243, 307 (1973) The Fail-Safe Society: Community Defiance and the End of American Technological Optimism by Charles Piller. University of California Press, \$12. See Nature 355, 124 (1992) The Formation of Science in Japan by James R. Bartholomew. Yale University Press, $\$ 23, £ 14.50$. See Nature 343 225 (1990) 